\title{
BIOREMEDIATION OF CONTAMINATED SOIL BY SLUDGE OIL USING THE BIOPILES AMELIORATED
}

\section{BIORREMEDIAÇÃO DE SOLO CONTAMINADO POR BORRA DE ÓLEO POR BIOPILHAS MELHORADAS}

\section{Eduardo Beraldo de Morais ${ }^{1}$; Sâmia Maria Tauk-Tornisielo² Ana Paula de Arruda Geraldes Kataoka ${ }^{3}$}

\author{
${ }^{1}$ Universidade Federal de Mato Grosso, Departamento de Engenharia Sanitária e \\ Ambiental, UFMG. E-mail dubmorais@yahoo.com.br \\ ${ }^{2}$ Centro de Estudos Ambientais, Universidade Estadual Paulista, Rio Claro, SP. E- \\ mail seb@rc.unesp.br \\ ${ }^{3}$ Centro de Controle de Zoonoses de São Paulo, Laboratório de Zoonoses e Doenças \\ Transmitidas por Vetores. E-mail apagk@terra.com.br
}

\begin{abstract}
The bioremediation of contaminated soil by sludge oil from petroleum refinery using amended biopiles through bio-stimulation and/or bio-augmentation was objective of this work. Four biopiles were constructed as follows: B1. control; B2. Bio-supplemented with oil-sludge-degrading bacteria and fungus; B3. Bio-supplemented and bio-stimulated with nutrients (N and P); B4. Biosupplemented and bio-stimulated with nutrients and rice husk. The study lasted 50 weeks and three different biodegradation stages were found during this period: an initial stage in which the reduction of oil and grease was greatest (up to 10 weeks); a stage with low biodegradation rates of the residue (10-30 weeks), and a late stage (30-50 weeks) in which it was observed an increase of the oily sludge biodegradation after the biopiles were covered with black plastic in thirtieth week. This procedure increased the internal temperature of biopiles and showed the importance of this parameter in the biodegradation process. The bio-stimulation using rice husk improved soil aeration and allowed the development of microorganisms added and increased their metabolic activities; consequently, the oil and grease removal was greater $(79.1 \%)$. The bacteria and fungus added in biopiles B2 and B3 did not survive, so it is necessary to produce inoculum more competitive and adapted. The biopiles system proved to be a viable technology for the bioremediation of soil polluted by oily sludge from petroleum refinery and the bio-stimulation by addition of materials such as rice husk increases its efficiency.
\end{abstract}

Keywords: Bio-augmentation. Bio-stimulation. Rice husk. Nutrients.

\section{RESUMO}

A biorremediação de solo contaminado por borra de óleo de refinaria de petróleo por meio de biopilhas bioestimuladas e/ou bioenriquecidas foi objetivo deste trabalho. Quatro biopilhas foram construídas, sendo: B1. controle; B2. adicionada de inóculo constituído por bactérias e fungos degradadores de borra de óleo; B3. adicionada de inóculo e nutrientes (N e P); B4. com inóculo, nutrientes e palha de arroz. $\mathrm{O}$ estudo se estendeu por 50 semanas e verificaram-se três estágios 
distintos de biodegradação durante este período: estágio inicial em que a redução de óleos e graxas foi mais intensa (até a semana 10); estágio com baixa taxa biodegradativa do resíduo (entre 10 e 30 semanas) e o último estágio (entre 30 e 50 semanas) com um aumento da biodegradação da borra de óleo após o recobrimento das biopilhas com uma lona plástica preta que ocorreu na trigésima semana. Esse procedimento aumentou a temperatura interna das biopilhas, destacando a importância desse parâmetro no processo de biodegradação. A adição de palha de arroz ao solo melhorou as condições de aeração, permitindo o desenvolvimento da microbiota adicionada e aumentando sua atividade metabólica o que levou a maior remoção de óleos e graxas $(79,1 \%)$. As bactérias e fungos adicionados em B2 e B3 não sobreviveram sendo necessário, portanto, a produção de inóculos mais adaptados e competitivos. O sistema de biopilhas demonstrou ser uma tecnologia viável para a biorremediação de solo contaminado por resíduos de refinaria de petróleo, e o bioestímulo por meio da adição de materiais como a palha de arroz aumenta sua eficiência.

Palavras-chave: Bioenriquecimento. Bioestímulo. Palha de arroz. Nutrientes.

\section{INTRODUCTION}

Considerable volumes of oily sludge have been generated during production, transportation, and refining processes of petroleum (CAMEOTRA and SINGH, 2008; TAHHAN and ABUATEIH, 2009). The composition of this residue is an emulsion of water, solids and petroleum hydrocarbons, mainly alkanes and paraffin of 1-40 carbon atoms, along with cycloalkanes and aromatic compounds, and its management and re-use is difficult because of its extremely variable composition (URURAHY et al., 1998; MARIN et al., 2005). Improper treatment and disposal of oily sludge leads to environmental pollution, particularly soil contamination, and poses a serious threat to groundwater. Petroleum hydrocarbons represent risks to the ecosystems and human health due to their toxicity and mutagenicity, making necessary measures to remediate these compounds in the environment (MORAIS and TAUK-TORNISIELO, 2009; TAHHAN and ABU-ATEIH, 2009).

Bioremediation of petroleum hydrocarbons polluted environments is a strategy that presents economic and environmental advantages. It makes use of microorganisms to degrade and transform large variety of dangerous substances, for example, the like petroleum hydrocarbons (ATLAS 1995; VASUDEVAN and RAJARAM 2001; BENTO et al., 2005; LIN et al., 2009). In Brazil, however, the bioremediation is not widely explored despite of the favorable climate and soil characteristics in this country being beneficial to bioremediation success.

Environmental factors play a vital role in the bioremediation of soil contaminated with hydrocarbons from petroleum: temperature, $\mathrm{pH}$, moisture, nutrient and oxygen availability, $\mathrm{C} / \mathrm{N}$ and C/P rates and contaminant availability (DIBBLE and BARTHA, 1979; CASTORENA-CORTÉS et al., 2009). Several strategies have been studied to control these factors and biostimulate the microbial activity to remediate the contaminated substrate. Rhykerd et al. (1999), Vasudevan and Rajaram (2001), and Xu and Lu (2010), for example, demonstrated that some low-density material (bulking agents) can promote better aeration of the polluted soil, facilitating the diffusion of oxygen, as well as increasing permeability and facilitating the contact of the microorganisms with water, nutrients and hydrocarbons. In the same way, the better ratio of carbon, nitrogen and phosphorous have been studied to accelerate the biological breakdown of hydrocarbons (ADMON et al., 2001; MARGESIN and SCHINNER, 2001; WANG et al., 2012).

The inoculation of hydrocarbon-degrading microorganisms in polluted areas is another strategy that can be used during bioremediation. Jacques et al. (2008) indicated that the bioaugmentation with bacteria and fungus isolated from a polycyclic aromatic hydrocarbon (PAHs) contaminated landfarm site was efficient during bioremediation of polluted soil with high concentration of anthracene, phenanthrene and pyrene. In other example, bacteria consortia of 
alkanes and polycyclic aromatic hydrocarbon degraders resulted in more than $30 \%$ increase in the overall removal of total petroleum hydrocarbons during a soil bioremediation (TAHHAN et al., 2011).

Soil bioremediation may be broadly divided into in situ and ex situ strategies. In situ bioremediation refers to the biological treatment of contaminated soil without excavating prior to treatment (SKLADANY and METTING, 1992; RHYKERD et al., 1999). In ex situ treatments the polluted soil is removed and remediated in another location (landfarming, composting, bioslurry and biopiles) using tilling, turning or continuously mixed slurries to apply oxygen and nutrients, and is performed in a prepared bed or reactor (XU and LU, 2010).

In this study, the bioremediation of oily sludge polluted soil using amended biopiles with oily-sludge-degrading microorganisms, nutrients $(\mathrm{N}$ and $\mathrm{P})$ and rice husk was evaluated. The microbial consortium was composed of selected bacteria and fungus from a landfarming of a petroleum refinery.

\section{MATERIAL AND METHODS}

\subsection{Oily sludge polluted soil}

The soil used to construct the biopiles was artificially polluted with the oily sludge that was taken from the bottom of storage tanks and treatment units at Brazilian Oil Refinery Replan (Petrobras S/A). The oily sludge was mixed together with sieved soil $(4.0 \mathrm{~mm})$ collected in the "Navarro de Andrade" State Forest (Rio Claro - SP - Brazil) in a proportion of approximately 5\% $\left(\mathrm{w} \mathrm{w}^{-1}\right)$ until a homogenous mixture was obtained. The soil was collected in an area never exposed to contamination. Physical-chemical characteristics of the oily sludge and clean soil are presented in Table 1.

Table 1 - Physical-chemical characteristics of oily sludge and clean soil.

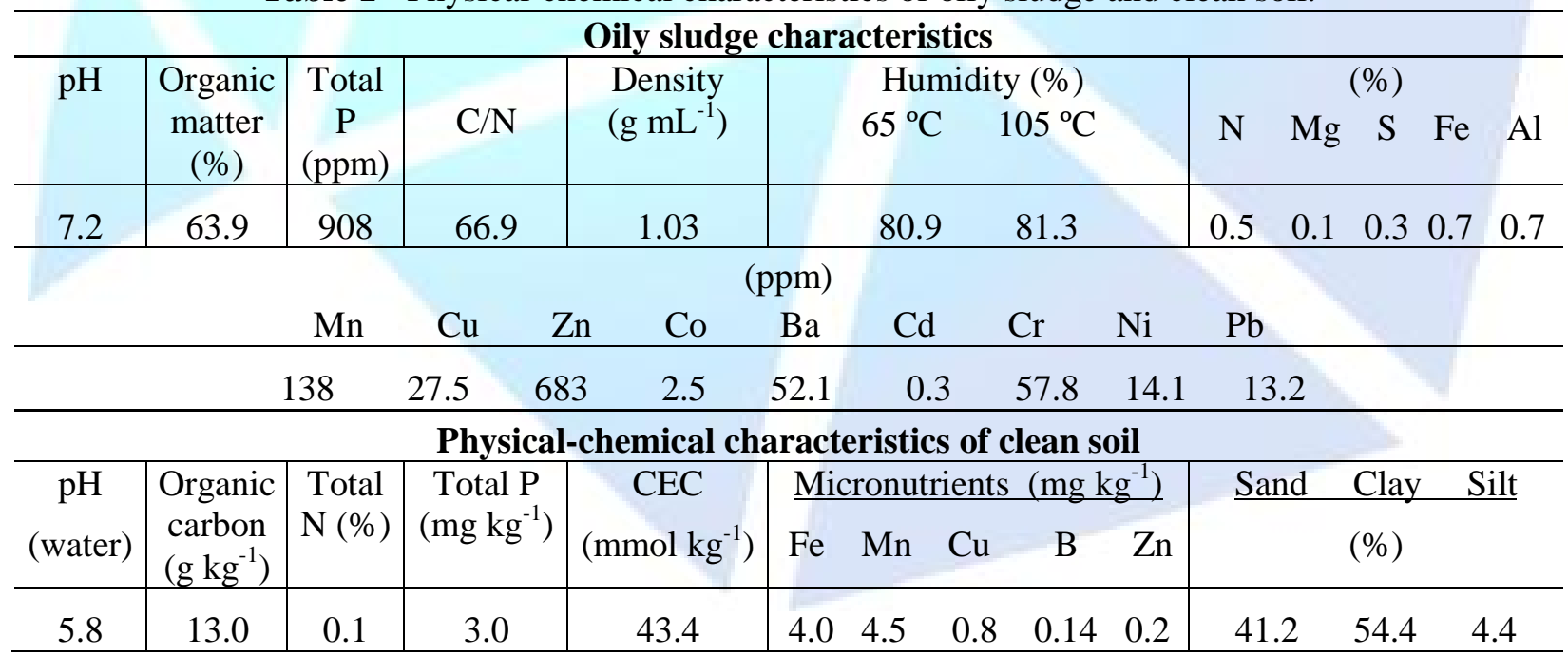

\subsection{Bioremediation in biopiles - experimental design}

Four biopiles were built with the oily sludge polluted soil as follows: B1. control; B2. Biosupplemented with oily-sludge-degrading bacteria and fungus; B3. Bio-supplemented and biostimulated with nutrients; B4. Bio-supplemented and bio-stimulated with nutrients and rice husk. The biopiles were built on an impermeable plastic tarp to prevent leaching of the pollutants into the sub-superficial environment. The dimensions of the biopiles were approximately $130 \mathrm{~cm}$ in length, 
$80 \mathrm{~cm}$ in width and $60 \mathrm{~cm}$ in height. Each biopile presented approximately $0.6 \mathrm{~m}^{3}$ of oily sludge polluted soil.

In biopiles B3 and B4 were added plant nutrients $\left(20 \mathrm{~g} \mathrm{~kg}^{-1}\right.$ soil $)$ composed of $10 \%$ total nitrogen, $10 \% \mathrm{P}_{2} \mathrm{O}_{5}$, and $10 \% \mathrm{~K}_{2} \mathrm{O}$. The concentration was calculated according to analyses of the soil and residue conducted beforehand to achieve a $\mathrm{C}: \mathrm{N}$ ratio of 30:1. In biopile $\mathrm{B} 4$, rice husk were added as bulking agent in the ratio of 1:15 of soil. Rice husk has been chosen because is readily available at minimal cost. The study period extended over 50 weeks. During the first 30 weeks, the biopiles were kept uncovered to increase aeration. After this period, the biopiles were covered with black plastic tarp to obtain higher temperatures and more constant moisture values. Every week, the soil in the biopiles was turned over to promote better aeration, and the moisture was maintained between 30 and $40 \%$.

\subsection{Isolation of oily-sludge-degrading microorganisms}

The oily-sludge-degrading bacteria and fungus were isolated from landfarming at the Brazilian Oil Refinery Replan by an enrichment method of oily-sludge-degrading microorganisms (KATAOKA, 2001). The method was based on a mixture of landfarming soil, oily sludge and garden soil (1:1:1) that was placed, after homogenization, in perforated PVC containers and underground completely in the garden soil at UNESP campus, at Rio Claro City, São Paulo, remaining exposed to the surrounding climatic conditions for 20 days. After this period, aliquots of $10 \mathrm{~g}$ were separated from containers and agitated with distilled and sterilized water for $15 \mathrm{~min}$, and the supernatant was then separated after a five minute rest period. Two $\mathrm{mL}$ of supernatant were transferred to an Erlenmeyer flask containing $100 \mathrm{~mL}$ of $\mathrm{BH}$ medium consists of, $\mathrm{g} \mathrm{L}^{-1}: \mathrm{MgSO}_{4}$ : $0.2 ; \mathrm{CaCl}_{2}: 0.02 ; \mathrm{K}_{2} \mathrm{HPO}_{4}: 1.0 ; \mathrm{K}_{2} \mathrm{HPO}_{4}: 1.0 ; \mathrm{NH}_{4} \mathrm{NO}_{3}: 1.0 ; \mathrm{FeCl}_{3}: 0.05$, and $1 \%$ of the oily sludge as the sole carbon source and it was incubated at $28{ }^{\circ} \mathrm{C}$ for 15 days. After, $2 \mathrm{~mL}$ were transferred from this Erlenmeyer flask to new flask with the same quantity of $\mathrm{BH}$ medium with $1 \%$ of the oily sludge and kept under the same conditions. Then, the oily-sludge-degrading bacteria and fungus were isolated from the two Erlenmeyer flasks containing the $\mathrm{BH}$ medium by using the pour plate technique in specific medium for each group: Nutrient Agar (NA) for bacteria (consists of, $\mathrm{g} \mathrm{L}^{-1}$ : peptone: 5.0; meat extract: 3.0; agar: 15.0; $\mathrm{pH}$ : 7.2) and Sabouraud-dextrose agar (SDA) for fungus (consists of, $\mathrm{g} \mathrm{L}^{-1}$ : peptone: 10.0; dextrose: 40.0; agar: 15.0; $\mathrm{pH}$ : 5.6). The isolated microorganisms were stored at $4{ }^{\circ} \mathrm{C}$ in specific medium for each group (NA and SDA).

Seven strains of fungus were isolated and identified based on reproductive structures as Trichoderma pseudokoningii, Eurotium amstelodami, Aspergillus flavus, Pseudallescheria boydii, Aspergillus versicolor, Aspergillus terreus and Cylindrocarpon didymium. Six strains of bacteria were isolated, one identified as Acinetobacter baumanii, three strains as Ochrobactrum anthropi, one as Bacillus cereus, and one strain was unidentified by traditional taxonomic standards. The Bergey's Manual of Determinative Bacteriology was used for identification (HOLT et al., 1994).

\subsection{Inoculum production}

An oily sludge/soil extract was obtained agitating the oily sludge polluted soil in distilled water (in ratio of 1:10) for $24 \mathrm{~h}$. It was enriched with $0.5 \%$ glucose and autoclaved at $121{ }^{\circ} \mathrm{C}, 40$ min and $1 \mathrm{~atm}$. This extract with glucose (SEG) was used as substrate to inoculum production and to induce the previous adaptation of oily-sludge-degrading microorganisms. In different Erlenmeyer flasks containing SEG, suspensions of each species of oily-sludge-degrading bacteria standardized together with a tube 8 of the MacFarland scale were added (ration of 1\%), and these flasks were agitated at $150 \mathrm{rpm}$ for three days at $35{ }^{\circ} \mathrm{C}$. The same procedure was used for the oily-sludgedegrading fungus except that spore suspensions of each strain standardized at $10^{7} \mathrm{~mL}^{-1}$ were used to inoculate $(1 \%)$ the SEG, and the flasks were agitated at $150 \mathrm{rpm}$ for five days at $28{ }^{\circ} \mathrm{C}$. Afterwards, these microorganisms, which had been grown separately in flasks containing SEG, were mixed to 
obtain the microbial consortium inoculum. Approximately $50 \mathrm{~mL}$ of inoculum were added for each kilogram of soil, with the exception of biopile B1, which was the control biopile. During the study period, inoculations were carried out on the first and thirty week of the experiment.

\section{biopiles \\ 2.5 Physic-chemical analysis and enumeration of culturable bacteria and fungus in}

Biopiles soil samples for chemical and microbiological analyses consisted of six subsamples (composite sample) collected randomly from different points in each biopile in a soil profile of $40 \mathrm{~cm}$. Each composite sample was mixing in plastic bag and stored at $4{ }^{\circ} \mathrm{C}$ for a maximum seven days if not analyzed immediately. The temperature $\left({ }^{\circ} \mathrm{C}\right)$ was measured directly in soil at a depth of $20 \mathrm{~cm}$ using a digital thermometer, at six randomly selected points in the biopiles. The soil moisture was measured calculating the difference between moist and dry weight after leaving the sample at $105{ }^{\circ} \mathrm{C}$ for $24 \mathrm{~h}$. The $\mathrm{pH}$ was determined with an electrode after $10 \mathrm{~g}$ of soil sample be agitated with $100 \mathrm{~mL}$ of distilled water for five minutes. These parameters were measured with weekly frequency in the first six weeks because it is waited that the easily biodegraded compounds are rapidly consumption by the microorganisms changing the conditions of the environment. After six week, the determination of these parameters occurred each two weeks (until 12-week); each four weeks (until 20-week); and each five weeks until the end of the experimental tests.

The pour plate count technique was used for the enumeration of culturable bacteria and fungus (CLARK, 1965). The plate count agar medium (PCA) was used to number bacteria (consists of, $\mathrm{g} \mathrm{L}^{-1}$ : tryptone: 5.0; yeast extract: 2.5; glucose: 5.0; agar: 15.0). For the fungus, Martin medium was used (consists of, $\mathrm{g} \mathrm{L}^{-1}$ : bacteriological peptone, 5.0; glucose: 10,$0 ; \mathrm{K}_{2} \mathrm{HPO}_{4}$ : $1.0 ; \mathrm{MgSO}_{4} 7 \mathrm{H}_{2} \mathrm{O}$ : 0,5; agar: $15.0 ; 5 \mathrm{mg}$ of streptomycin sulfate; $100.0 \mathrm{~mL}$ rose Bengal solution; $900.0 \mathrm{~mL}$ of distilled water and). The colonies were counted following incubation for three days at $35{ }^{\circ} \mathrm{C}$ for bacteria, and five days at $28^{\circ} \mathrm{C}$ for fungi. All the determinations were carried out in triplicate.

The biopiles soils were sampled at $0,2,4,7,10,15,20,2530,35,43,50$ weeks for the determination of oil and grease (O\&G) content. The soils samples were first dried at $60{ }^{\circ} \mathrm{C}$ for $48 \mathrm{~h}$ to prevent the interference of moisture. The $O \& G$ content were calculated gravimetrically after extraction with hexane (APHA, 1998).

\subsection{Kinetics biodegradation}

In this study a first-order model was selected to characterize the oil and grease removal during the bioremediation process (ADMON et al., 2001). The equation was given by $\ln \left(C / C_{0}\right)=-k t$, where $C_{0}$ is the initial O\&G concentration ( $\mathrm{g}$ of $\mathrm{O} \& \mathrm{G} / \mathrm{g}$ of dry soil), $C$ is the $\mathrm{O} \& \mathrm{G}$ concentration $(\mathrm{g}$ of $\mathrm{O} \& \mathrm{G} / \mathrm{g}$ of dry soil), $k$ a biodegradation constant obtained by regression linear (semana ${ }^{-1}$ ) and $t$ the period of the experiments (weeks). Three stages of O\&G biodegradation were considered: the first ten weeks; 10-30 weeks; and 30-50 weeks.

\section{RESULTS AND DISCUSSION}

\subsection{Enumeration of microorganisms in biopiles}

The initial bacteria count in soil of the biopiles was $1.9 \times 10^{6}$ colony-forming units (CFU) $\mathrm{g}^{-1}$ dry soil (Figure 1a). In biopile B1 (control) it was observed an increase to $2.5 \times 10^{7} \mathrm{CFU} \mathrm{g}^{-1}$ dry soil at 8-week sample; this suggested that the bacteria from the soil and oily sludge can utilize the residue with production of new cells. In biopiles B2 and B3 which received inoculum and inoculum and nutrients respectively, the bacteria added did not survive. The numbers of bacteria in CFU in these biopiles were similar to the results obtained in control biopile (B1), except when inoculations 
were applied. At 2-week, the biopile B4 recorded the highest amount of bacteria, $2.1 \times 10^{8} \mathrm{CFU} \mathrm{g}^{-1}$ dry soil, and then a gradually decreased until 30 weeks was observed; after the second inoculation the bacteria count increased to $1.2 \times 10^{8} \mathrm{CFU} \mathrm{g}^{-1}$ dry soil and decreased to $4.3 \times 10^{7} \mathrm{CFU} \mathrm{g}{ }^{-1}$ dry soil at 50 weeks.

Figure $1 \mathrm{~b}$ shows that fungus initial count was $5.7 \times 10^{4} \mathrm{CFU} \mathrm{g} \mathrm{g}^{-1}$ dry soil of the biopiles and an increase occurred in biopile B1 until 4-week, when $8.5 \times 10^{5} \mathrm{CFU} \mathrm{g}{ }^{-1}$ dry soil was observed. In biopile B4 it was observed the higher quantities of fungus (variation between $2.5 \times 10^{6}$ and $1.2 \mathrm{x}$ $10^{7} \mathrm{CFU} \mathrm{g^{-1 }}$ dry soil); it is evident that rice husk presents an important function in the development of microbiota (fungus and bacteria). This material prevented the soil from becoming compacted and further improved the soil aeration, creating favorable conditions for microbial development and metabolic activity. According to Trémier et al. (2009) the air dispersion, consolidation and oxygen uptake are all influenced by a bulking agent during a sludge composting procedure. In the same way, Wang et al. (2012) reported that the pore structure of soil in biopiles composed of aged oily sludge was improved by the addition of bulking agent which caused an improvement in microbial activity and biodegradation of organic matter. The fungal inoculum added in biopiles B2 and B3 did not survive so it is necessary to ensure that during the inoculum production the oily-degrading microorganisms can become competitive to survive in the polluted area. The bioaugmentation has shown good results when applied in laboratory scale (VASUDEVAN and RAJARAM, 2001, YERUSHALMI et al., 2003; BENTO et al., 2005) but when it is applied in the field sometimes the results are not promising as those obtained in laboratory because of inefficiency of inoculum to survive at polluted site (BALBA et al., 1998; SIMON et al., 2004). Morais and Tauk-Tornisielo (2009) suggested that microbial strains isolated from environments impacted by dangerous substances should be stored in laboratory conditions very similar to the environments from which they were isolated. This should be done to maintain their existing characteristics and prevent the loss of metabolic activity related to hazardous compounds biodegradation.
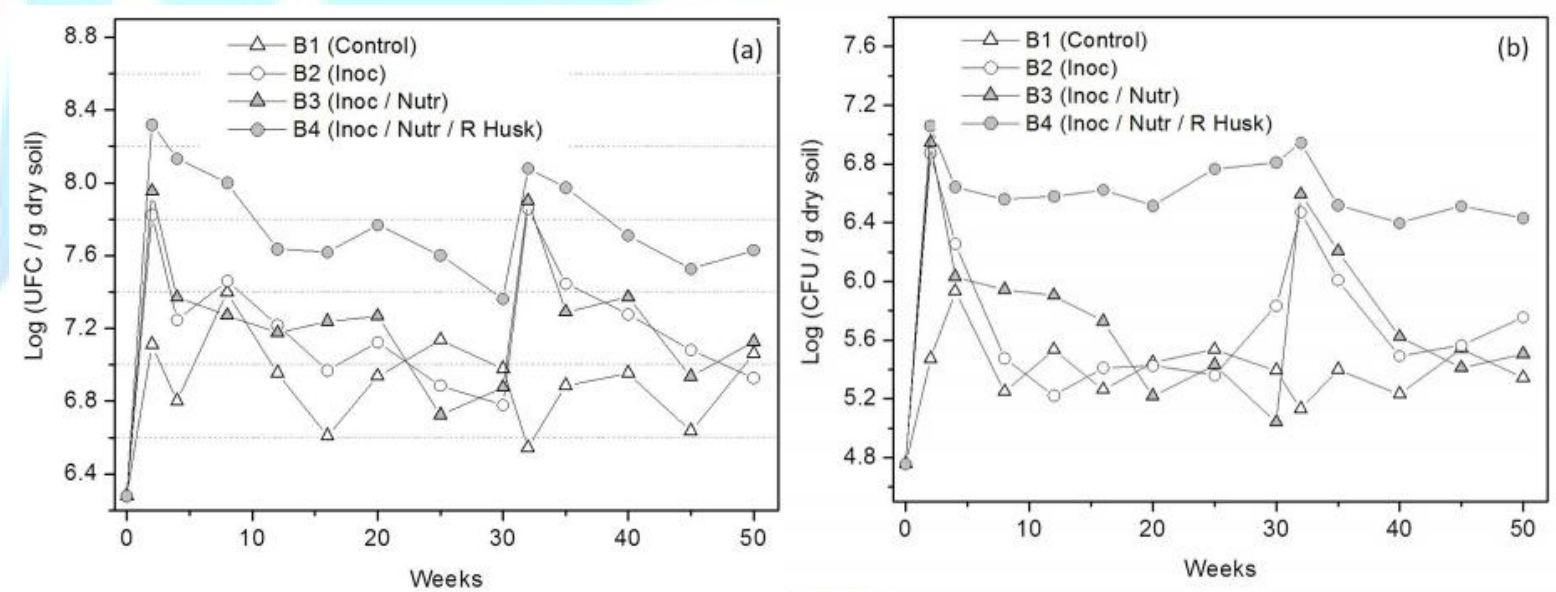

Figure 1. Microorganisms enumeration in the biopiles during the bioremediation: (a) bacteria (b) fungus.

\subsection{Temperature and $\mathrm{pH}$}

During 0-30 weeks the biopiles were kept uncovered to increase aeration since the biodegradation process is mainly aerobic. In this stage, the higher temperature was recorded in the biopile B4 $\left(29.1^{\circ} \mathrm{C}\right)$, in the first week (Figure 2a). The biodegradation of hydrocarbons can occur in a wide range of temperatures $\left(0\right.$ to $\left.70{ }^{\circ} \mathrm{C}\right)$, but the optimal temperature for this process has been reported to be 30 to $40{ }^{\circ} \mathrm{C}$ (ROSATO, 1997). In general, low temperatures increase the viscosity of 
the oil, reduce the volatility of the short chain alkanes and are also associated with a reduction in enzymatic activity, slowing down the process of biodegradation. After slight increase of temperatures in the first weeks, the values of this parameter declined until 20-week and the temperatures values recorded were not optimum to hydrocarbons biodegradation.

The biopiles were covered during 30 weeks with a black plastic tarp, and a significant increase in temperature was observed in the biopiles, with some values exceeding the air temperature. The highest mean value recorded in the study was noted in biopile $\mathrm{B} 4\left(38.5{ }^{\circ} \mathrm{C}\right)$ at 45 weeks (Figure 2a). The use of black plastic tarp to cover the oil polluted soil during the bioremediation can stimulate oil biodegradation as a consequence of the temperature increased; however, to avoid a reduction in soil aeration it is necessary to turn it over frequently.

A decline in the $\mathrm{pH}$ values was observed for the four biopiles studied in the first 20 weeks (Figure 2b). However, in biopiles B3 and B4, which received nutrients, an increase occurred during the first 4 weeks and the higher $\mathrm{pH}$ values, 7.9 and 8.0, respectively, were recorded. The biodegradation of hydrocarbons begins with the liberation of carboxylic radicals and consequent formation of organic acids responsible for the acidification of the substrate. The optimal $\mathrm{pH}$ range for the degradation of hydrocarbons has been reported to be between 6 and 8 (Morgan and Watkinson, 1989). In an attempt to accelerate the biodegradation process, lime was added at 20week to raise the $\mathrm{pH}$ values to levels above 6 . At 50 weeks the $\mathrm{pH}$ values of biopiles were between 5.5 and 6.5 .
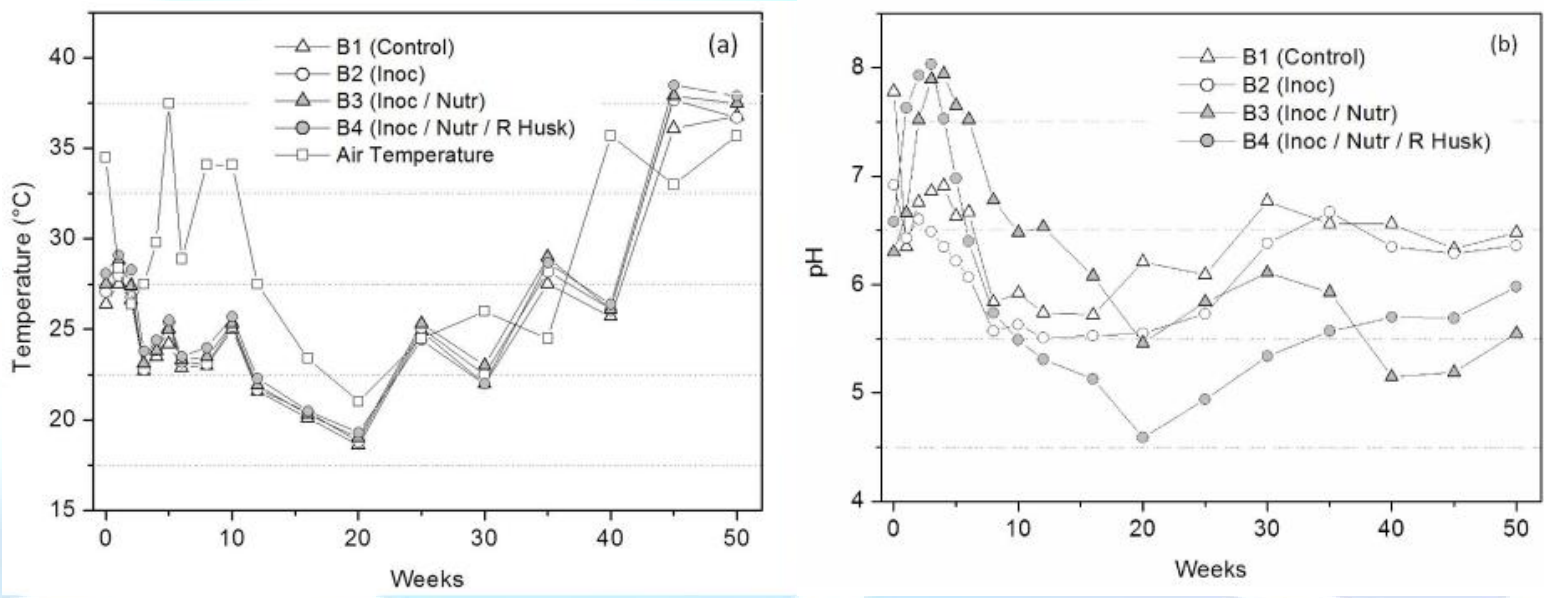

Figure 2. (a) Temperatures compared to the air temperature and (b) $\mathrm{pH}$ in biopiles during bioremediation process.

\subsection{Oil and grease (O\&G) content}

Figure 3 shows the oil and grease $(\mathrm{O} \& \mathrm{G})$ reduction in biopiles during bioremediation experiments. After 50 weeks, $33.1 \%, 30.1 \%, 25.0 \%$ and $20.9 \%$ of O\&G remained in biopiles B1, B2, B3 and B4, respectively. O\&G initial content was $27220 \mathrm{mg} / \mathrm{Kg}$ dry soil. The data (Figure 3) showed three patterns occurring during bioremediation in biopiles: stage 1 ( 0 -10 weeks) where the process was characterized by a period of fast decrease in O\&G concentration; stage 2 (10-30 weeks), a period with the smallest biodegradation rates of residue; and stage 3 (30-50 weeks) with a new increase in the $\mathrm{O} \& \mathrm{G}$ biodegradation after the covering of biopiles. The regression analyses were performance for each phase and results for the kinetic analyses are presented at Table 2 .

At 10 -week, $44.1 \%$ of O\&G remained in biopile B4; this mean that $55.9 \%$ of the oily residue was degraded in this period and only $22.2 \%$ was degraded in the next 40 weeks. In the other biopiles, B1, B2 and B3, the biodegradation rate of residue at 10 -week were $40.1 \%, 47.8 \%$ and 
$49.3 \%$ respectively. The oily sludge is consisting of some compounds that are easily biodegraded and probably were consumption rapidly at begin of the study and the compounds that are more resistance to degradation were consumed slowly.

Large molecules and polycyclic aromatic molecules are examples for recalcitrant compounds while linear and open-chain hydrocarbons are more easily biodegraded. In the stage 1 (0-10 weeks), biopile B4 presented the higher biodegradation rate constant $\left(k_{l}=0.084\right.$ week $^{-1} ; \mathrm{R}^{2}=$ $0.90)$ followed by biopile B3 $\left(k_{1}=0.070\right.$ week $\left.^{-1} ; \mathrm{R}^{2}=0.96\right)$ (Table 2). This can explain the temperature values observed in biopile B4 that were $1-2{ }^{\circ} \mathrm{C}$ higher than the values observed in the control biopile (B1) in stage 1 (0-10 weeks) (Figure 2a). In B4 the heat released due the breakdown of chemical bonds of the molecules from residue was greater than in other biopiles.

At stage 2 of bioremediation (10-30 weeks) it was observed that the $k_{2}$ values were low with a variation between $0.007\left(R^{2}=0.71\right)$ in $B 4$ and $0.013\left(R^{2}=0.79\right)$ in B3 (Table 2). It was found in this stage the lowest values of temperature that may have influenced the slower biodegradation rates in the biopiles. After the covering of the biopiles in the 30-week, it was observed an increased in the $k_{3}$ of biopiles B2, B3 and B4 (Table 2). This measure favored the increase of temperature inside the biopiles, with mean values near $40{ }^{\circ} \mathrm{C}$, and helped maintain constant the moisture of the soil, between 30 and $40 \%$, which has not previously been verified in this study. The importance of the temperature for the biodegradation of the oily sludge became evident, since as mentioned previously. The metabolic processes that involve the catabolic pathways of hydrocarbon degradation are directly related to this parameter. Gray et al. (2000) conducted bioremediation of hydrocarbons contaminated soil on a laboratory scale and found that increasing temperature from $21{ }^{\circ} \mathrm{C}$ to $30{ }^{\circ} \mathrm{C}$ was beneficial for removal of this pollutant.

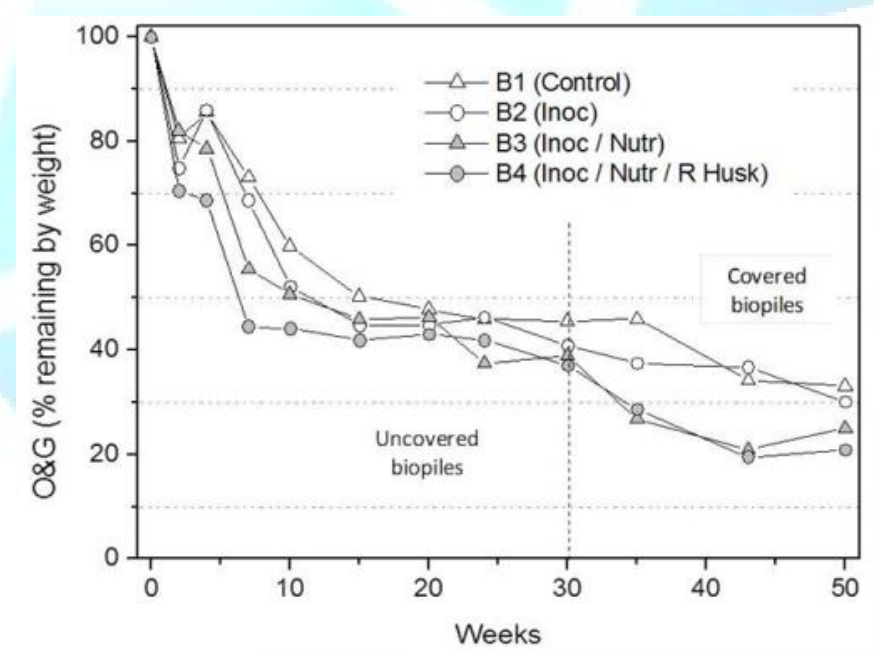

Figure 3. Oil and grease $(\mathrm{O} \& \mathrm{G})$ reduction in biopiles. Initial amount of $O \& G$ was $27220 \mathrm{mg} / \mathrm{Kg}$ dry soil.

Table 2 - Biodegradation rate constants: $k_{1}, k_{2} \mathrm{e} k_{3}$ are the first order rate constant derived for the first, second and third stages of bioremediation, respectively.

\begin{tabular}{ccccccc}
\hline \multirow{2}{*}{ Biopile } & $\begin{array}{c}\text { Stage } 1 \\
(10 \text { weeks })\end{array}$ & \multicolumn{2}{c}{$\begin{array}{c}\text { Stage } 2 \\
(10-30 \text { weeks })\end{array}$} & \multicolumn{2}{c}{$\begin{array}{c}\text { Stage 3 } \\
(30-50 \text { weeks })\end{array}$} \\
\cline { 2 - 7 } & $k_{l}\left(\right.$ week $\left.^{-1}\right)$ & $\mathrm{R}^{2}$ & $k_{2}\left(\right.$ week $\left.^{-1}\right)$ & $\mathrm{R}^{2}$ & $k_{3}\left(\right.$ week $\left.^{-1}\right)$ & $\mathrm{R}^{2}$ \\
\hline B1 & 0.045 & 0.90 & 0.013 & 0.80 & 0.013 & 0.87 \\
B2 & 0.056 & 0.84 & 0.010 & 0.71 & 0.022 & 0.56 \\
B3 & 0.070 & 0.96 & 0.015 & 0.79 & 0.036 & 0.96 \\
B4 & 0.084 & 0.90 & 0.007 & 0.71 & 0.030 & 0.81 \\
\hline
\end{tabular}




\section{CONCLUSIONS}

The addition of bulking agent, like rice husk used in this study, amended soil characteristics of biopile especially pore structure, created conditions to the microbial development and their metabolic activities and increased the biodegradation of oily sludge especially in the first 10 weeks. The covering of biopiles was useful to accelerate the oily sludge biodegradation indicating that the temperature is also an important factor to the bioremediation success of hydrocarbons polluted soil. It is necessary to produce adapted inoculum to ensure that the microorganisms added in the oil polluted soil can survive. Biopiles are a good alternative to bioremediate oil polluted soil with saving extra money when material like rice husk (bulking agents) were used.

\section{ACKNOWLEDGMENTS}

The authors are grateful to Fundação de Amparo à Pesquisa do Estado de São Paulo (FAPESP) for research funds and grants.

\section{REFERENCES}

ADMON, S.; GREEN, M.; AVNIMELECH, Y. Biodegradation kinetics of hydrocarbons in soil during land treatment of oily sludge. Bioremediation Journal, Philadelphia v. 5, p. 193-209, 2001.

APHA - AMERICAN PUBLIC HEALTH ASSOCIATION. Standard methods for the examination of water and wastewater. 20 ed. Washington: American Public Health Association, AWWA, WPCF, 1998. 1569p.

ATLAS, R.M. Petroleum biodegradation and oil spill bioremediation. Marine Pollution Bulletin, Oxford, v. 31, p. 178-182, 1995.

BALBA, M.T.; AL-AWADHI, N.; AL-DAHER, R. Bioremediation of oil-contaminated soil: microbiological methods for feasibility assessment and field evaluation. Journal of Microbiological Methods, Amsterdam, v. 32, p. 155-164, 1998.

BENTO, F.M.; CAMARGO, F.A. O.; OKEKE, B.C.; FRANKENBERGER, W.T. Comparative bioremediation of soil contaminated with diesel oil by natural attenuation, biostimulation and bioaugmentation. Bioresource Technology, Essex, v. 96, p. 1049-1055, 2005.

CAMEOTRA, S.S.; SINGH, P. Bioremediation of oil sludge using crude biosurfactants. International Biodeterioration \& Biodegradation, Oxford, v. 62, p. 274-280, 2008.

CASTORENA-CORTÉS, G.; ROLDÁN-CARRILLO, T.; ZAPATA-PEÑASCO, I.; REYESAVILA, J.; QUEJ-AKÉ, L.; MARÍN-CRUZ, J.; OLGUÍN-LORA, P. Microcosm assays and Taguchi experimental design for treatment of oil sludge containing high concentration of hydrocarbons. Bioresource Technology, Essex, v. 100, p. 5671-5677, 2009.

CLARK, F.E. Agar-plate method for total microbial count. In: C.A. BLACK; D. EVANS; J.L. WHITE; L.E. ENSMINGER; F.E. CLARK E R.C. DINAUER (Ed.), Methods of soil analysis. New York: Madson, 1965, p.1460-1466. 
DIBBLE, J.T.; BARTHA, R. Effect of environmental parameters on the biodegradation of oil sludge. Applied and Environmental Microbiology, Washington, v. 37, p. 729-739, 1979.

GRAY, M.R.; BANERJEE, D.K.; DUDAS, M.J.; PICKARD, M.A. Protocols to enhanced biodegradation of hydrocarbons contaminants in soil. Bioremediation Journal, Philadelphia, v. 4, n. 4, p. 249-257, 2000.

HOLT, J.G.; KRIEG, N.R.; SNEATH P.H.; STALEY, J.T.; WILLIAMS S. Bergey`s Manual of Determinative Bacteriology. 9th ed. Williams \& Wiilkins: Baltimore, 1994, 787 p.

JACQUES, R.J.S.; OKEKE, B.C.; BENTO, F.M.; TEIXEIRA, A.S.; PERALBA, M.C.R.; CAMARGO, F.A.O. Microbial consortium bioaugmentation of a polycyclic aromatic hydrocarbons contaminated soil. Bioresource Technology, Essex, v. 99, p. 2637-2643, 2008.

KATAOKA, A.P.A.G. Biodegradação de resíduos oleosos de refinaria de petróleo por microrganismos isolados de landfarming, 2001. 202f. Tese (Doutorado em Microbiologia Aplicada) - Instituto de Biociências, Universidade Estadual Paulista, Rio Claro, 2001.

LIN, X.; LI, X.; SUN, T.; LI, P.; ZHOU, Q.; SUN, L.; HU, X. Changes in microbial populations and enzyme activities during the bioremediation of oil-contaminated soil. Bulletin of Environmental Contamination and Toxicology, New York, v. 83, p. 542-547, 2009.

MARGESIN, R.; SCHINNER, F. Bioremediation (natural attenuation and biostimulation) of dieseloil-contaminated soil in an Alpine glacier skiing area. Applied and Environmental Microbiology, Washington, v. 67, n. 7, p. 3127-3133, 2001.

MARIN, J.A.; HERNANDEZ, T.; GARCIA C. Bioremediation of oil refinery sludge by landfarming in semiarid conditions: Influence on soil microbial activity. Environmental Research, New York, v. 98, p. 185-195, 2005.

MORAIS, E.B.; TAUK-TORNISIELO, S.M. Biodegradation of oil refinery residues using mixedculture of microorganisms isolated from a landfarming. Brazilian Archives of Biology and Technology, Curitiba, v. 52, n. 6, p. 1571-1578, 2009.

MORGAN, P.; WATKINSON, R.J. Hydrocarbon degradation in soils and method for soil biotreatment. Critical Reviews in Biotechnology, New York, v. 8, p. 305-333, 1989.

ROSATO, Y.B. Biodegradação do petróleo. In: MELO, I. S.; AZEVEDO, J. L. Microbiologia Ambiental. EMBRAPA, São Paulo. 1997, p. 307-304.

RHYKERD, R.L.; CREWS, B.; MCINNES, K.J.; WEAVER, R.W. Impact of bulking agents, forced aeration, and tillage on remediation of oil-contaminated soil. Bioresource Technology, Essex, v. 67, p. 279-285, 1999.

SIMON, M.A.; BONNER, J.S.; PAGE, C.A.; TOWNSEND, R.T.; MUELLER, D.C.; FULLER, C.B.; AUTENRIETH, R.L. Evaluation of two commercial bioaugmentation products for enhanced removal of petroleum from a wetland. Ecological Engineering, v. 22, p. 263-277, 2004. 
SKLADANY, G.J.; METTING, F.B. Bioremediation of contaminated soil. In: METTING, F. B.; (Ed.). Soil microbial ecology: application in agricultural an environmental management. New York: Marcel Dekker Inc, 1992. p. 483-513.

TAHHAN, R.A.; ABU-ATEIH, R.Y. Biodegradation of petroleum industry oily-sludge using Jordanian oil refinery contaminated soil. International Biodeterioration \& Biodegradation, Oxford, v. 63, p. 1054-1060, 2009.

TAHHAN, R.A.; AMMARI, T.G.; GOUSSOUS, S.J.; AL-SHDAIFAT, H.I. Enhancing the biodegradation of total petroleum hydrocarbons in oily sludge by a modified bioaugmentation strategy. International Biodeterioration \& Biodegradation, Oxford, v. 65, p. 130-134, 2011.

TRÉMIER, A.; TELIA, C.; BARRINGTON, S. Effect of initial physical characteristics on sludge compost performance. Bioresource Technology, Essex, v. 100, p. 3751-3758, 2009.

URURAHY, A.F.P.; MARINS, M.D.M.; VITAL, R.L.; GABARDO, I.T. PEREIRA Jr, N. Effect of aeration on biodegradation of petroleum waste. Revista de Microbiologia, São Paulo, v. 29, p. 254$258,1998$.

WANG, X.; WANG, Q.; WANG, S.; LI, F.; GUO, G. Effect of biostimulation on community level physiological profiles of microorganisms in field-scale biopiles composed of aged oil sludge.

Bioresource Technology, Essex, v. 111, p. 308-315, 2012.

VASUDEVAN, N.; RAJARAM, P. Bioremediation of oil sludge-contaminated soil.

Environmental International, Elmsford, v. 26, p. 409-411, 2001.

XU, Y.; LU, M. Bioremediation of crude oil-contaminated soil: Comparison of different biostimulation and bioaugmentation treatments. Journal of Hazardous Materials, v. 183, p. 395$401,2010$.

YERUSHALMI, L.; ROCHELEAU, S.; CIMPOIA, R.; SARRAZIN, M.; SUNAHARA, G.; PEISAJOVICH, A.; LECLAIR, G.; GUIOT, S.R. Enhanced biodegradation of petroleum hydrocarbons in contaminated soil. Bioremediation Journal, Philadelphia v. 7, n. 1, p. 37-51, 2003. 